\title{
A new Sigelgaita Heinrich (Lepidoptera, Pyralidae, Phycitinae) feeding on cacti in Brazil
}

\author{
Ricardo F. Monteiro ${ }^{1}$ \\ Vitor O. Becker ${ }^{2}$
}

\begin{abstract}
Description and biological aspects of a new species of Sigelgaita Heinrich, 1939, the first known to occur east of the Andes, S. cerei Becker, are presented. S. cerei larvae were collected on "restinga" ecosystems feeding on Pilosocereus arrabidae (Lem.) Byles \& Rowl. (Parque Nacional da Restinga de JurubatibaMacaé and Área de Proteção Ambiental de Barra de Marica, Rio de Janeiro) and rarely on Cereus obtusus Haw. (PNRJ). Life cycle and behavior of larvae are presented. Larvae are found singly on flower buds, on fruit or more frequently on stem of the plants. They build chambers in the cladodium where they complete their larval development, then droping to the ground in order to pupate. Trichogramma sp. was parasitizing $72 \%$ of eggs and a species of braconid was parasitizing half out of ten larvae collected from fruits of Cereus obtusus. S. cerei larvae develop a special role in the colonization and establishment of a diverse fauna associates with the hosts such as insects, spiders and yeasts. Ants, such as Camponotus crassus Mayr, 1862 and C. cingulatus Mayr, 1862 are among the insects which most frequently nest in the chambers abandoned by the larvae of this moth species.

KEY WORDS. Sigelgaita, Pyralidae, Cactaceae, Restinga, insect-plant interaction, Neotropical region
\end{abstract}

The genus Sigelgaita Heinrich, 1939 includes three cactus-feeding species from the Andes and the Pacific coast of Peru and Chile (HEINRICH 1956: 255). The species described below is the first known to occur east of the Andes.

Abbreviations used here are as follows: $\mathrm{CNPq}$ (Conselho Nacional de Desenvolvimento Científico e Tecnológico), FAPERJ (Fundação de Amparo à Pesquisa do Estado do Rio de Janeiro), IBAMA (Instituto Nacional de Meio Ambiente), MNRJ (Museu Nacional, Rio de Janeiro), USNM (National Museum of Natural History, Washington) and VOB (Becker Collection, Brasilia).

\section{Sigelgaita cerei Becker, sp. nov.}

Figs 1-12

Males 15-17 mm, females 16-18 mm. Head whitish, irrorated grey. Antennae pectinate, fuscous. Thorax whitish, mixed with blackish scales; posterior margin, including margins of tegulae, dark fuscous. Forewings whitish, speckled with blackish

1) Departamento de Ecologia, Instituto de Biologia, Universidade Federal do Rio de Janeiro. Caixa Postal 68020, 21941-590 Rio de Janeiro, Rio de Janeiro, Brasil. E-mail: monteiro@biologia.ufrj.br

2) Pesquisador Associado, Departamento de Zoologia, Universidade de Brasília. Caixa Postal 04525, 70919-970 Brasília, Distrito Federal. E-mail: vbecker@serrabonita.org 


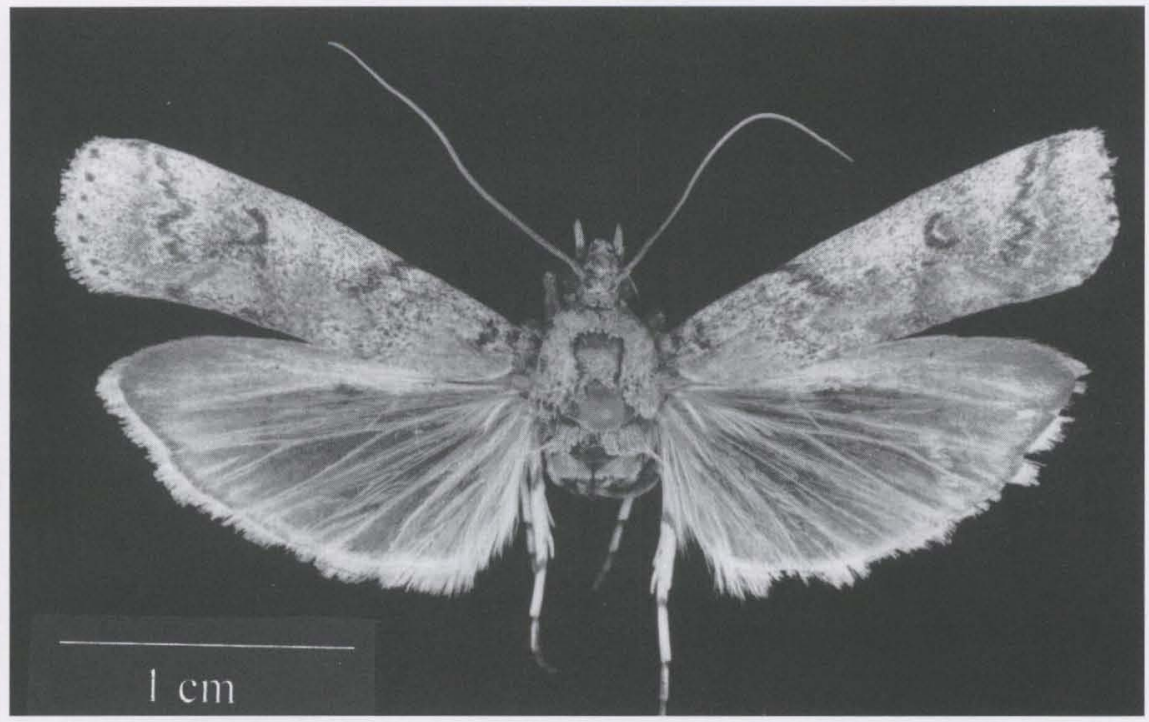

Fig. 1. Sigelgaita cerei Becker, sp. nov. female paratype.

and ferrugineous scales; basal, antemedial and subterminal lines double, irregular, blackish; reniform spot conspicuous, ill marked distad, filled whitish; black dots along termen, on vein interspaces. Hind wings semitransluscent white, costa and termen narrowly dusted fuscous. Legs whitish, irrorated grey, ringed grey on articulations.

Abdomen grey, banded whitish dorsally, whitish ventraly.

Females (Fig. 1). Slightly darker than males, antennae filiform, whitish, ringed dark. Forewings broader than those of males.

Male genitalia (Figs 2 and 3). Almost identical to those of S. transilis Heinrich, 1939, except for the absence of "elements of transtilla" of HEINRICH (1956: 442, figs 553, 553a), and for the presence of a cluster of spines on base of vesica (Fig. 3), absent in that of $S$. transilis.

Female genitalia(Fig. 4). Also similar to those of the other Sigelgaita species, except for ductus bursae proporcionally longer and narrow for most of its length, not widening gradually towards corpus bursae, as in the other species. Signum represented by a vestigial, short spine, opposite to insertion of ductus seminalis.

Material studied. HOLOTYPE male, BRAZIL, Rio de Janeiro: Maricá, 5 m, 12-15.01.1985 (Becker), at MV light (VOB). Paratypes. 1 male, 1 female same data as holotype (USNM, VOB); 1 male, 3 females: same locality and collector but 11.10.1985 (USNM, VOB); 1 female: RJ, Arraial do Cabo, 50m, 29.01.1985 (Becker) (VOB); 1 female, 1 male: Macaé, 50m, 24.10.2001[MNRJ, RFM].

Remarks. One paratype was compared with the type-material of the three previous described species, in USNM, and did not match any of them. Externally this species resembles S. chilensis Heinrich, 1939, however, its male genitalia are closer to those of $S$. transilis. In $S$. chilensis the valvae are much broader while in 

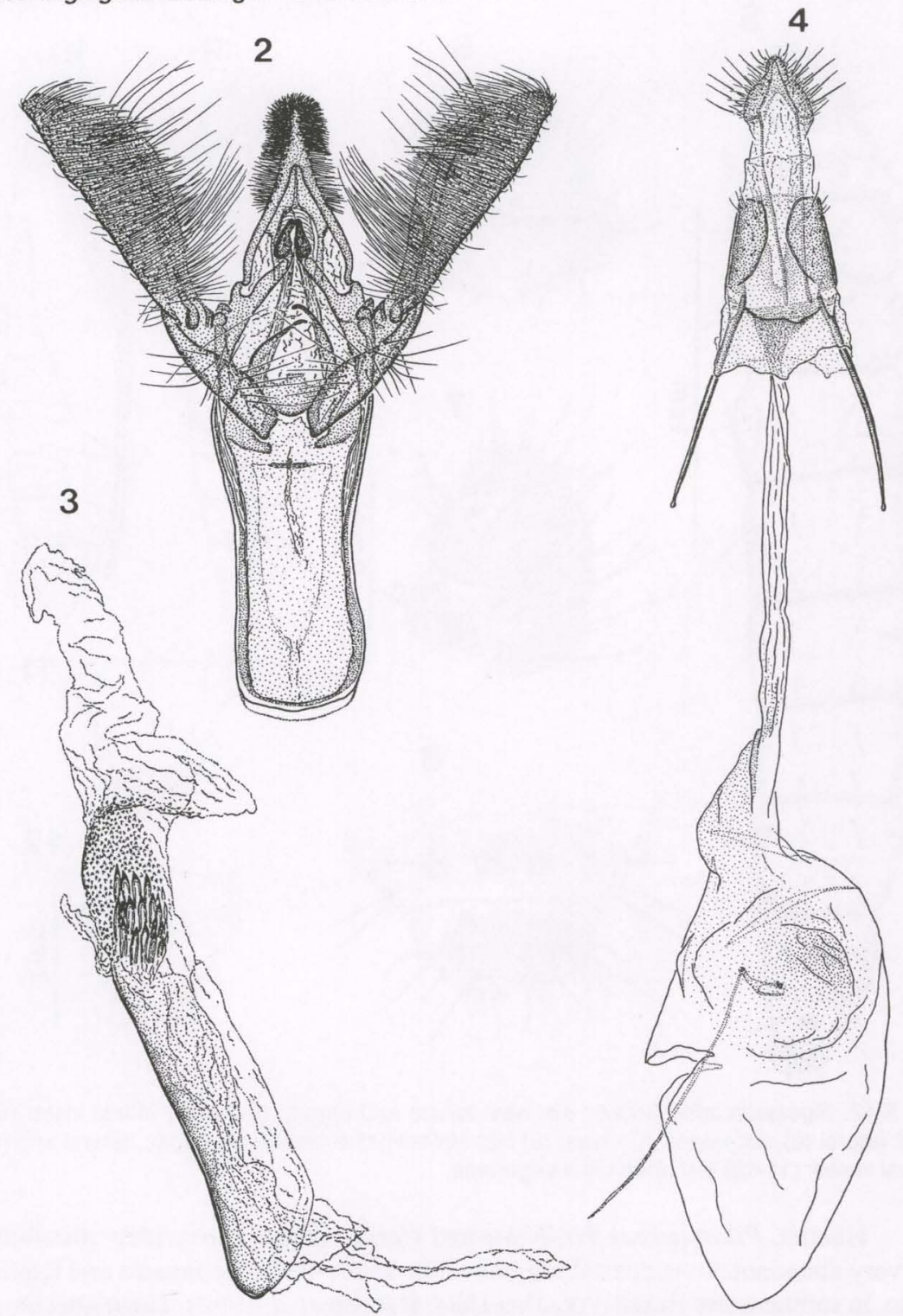

Figs 2-4. Genitalia of Sigelgaita cerei Becker, sp. nov. paratypes: (2) male with aedeagus removed; (3) aedeagus; (4) female.

S. cerei they are narrow, and also has the saccus long, as in S. transilis. Externally $S$. transilis is very distinct: forewings dark grey; males showing strongly pectinate antennae.

Host plants. Pilosocereus arrabidae (Lem.) Byles \& Rowl. and Cereus obtusus Haw. (Cactaceae). 

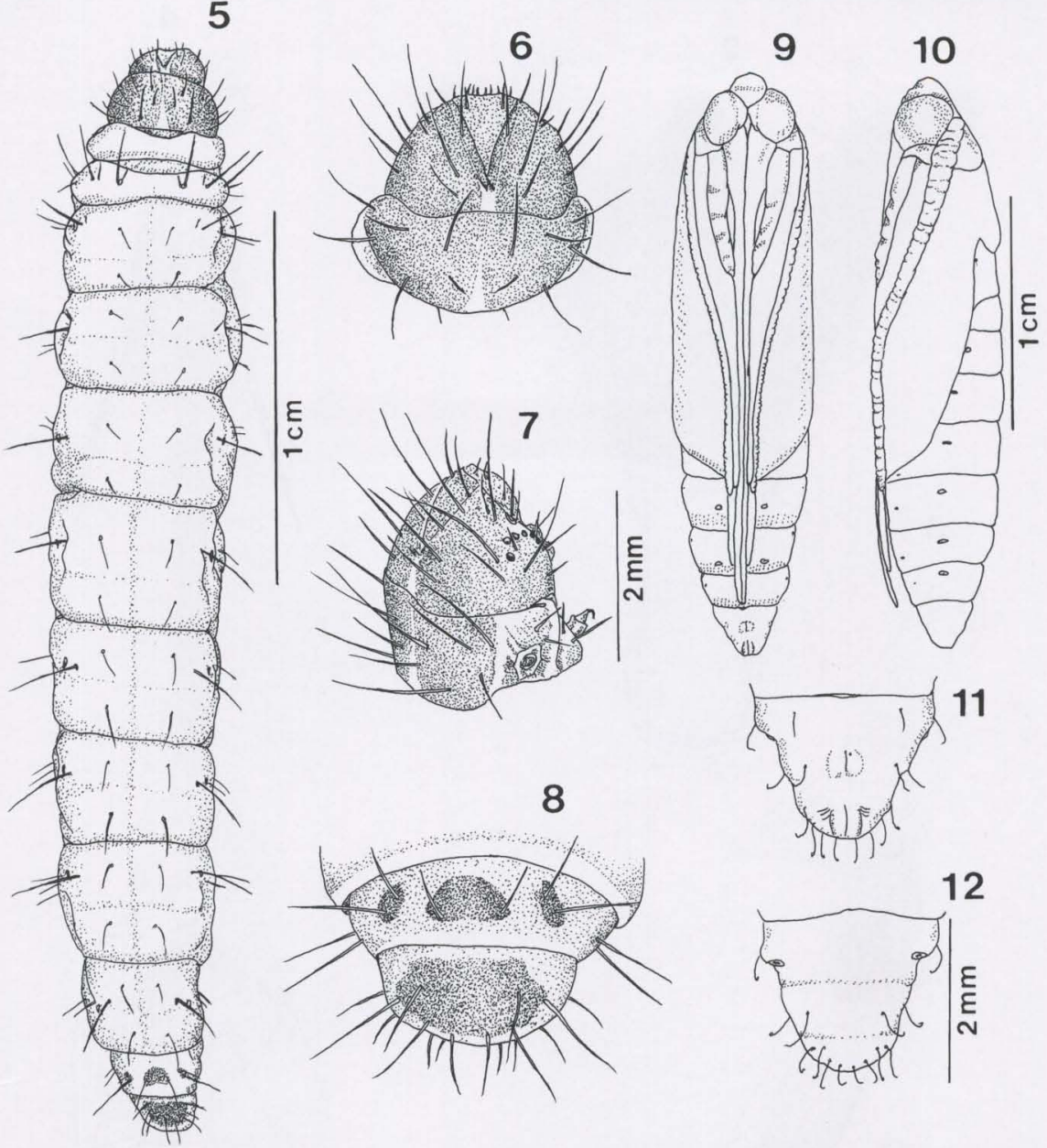

Figs 5-12. Sigelgaita cerei Becker, sp. nov. larvae and pupae: (5) larvae of last instar $\left(5^{\text {th }}\right)$, head, lateral (6) and upper (7) views; (8) last abdominal segment; (9) pupae, lateral and (10) ventral views; (11-12) last abdominal segments.

Habitat. Pilosocereus arrabidae and Cereus obtusus are widely distributed and very abundant along coastal regions of the states of Rio de Janeiro and Espírito Santo, in southeastern Brazil (ARAÚJO 1984; RIZZINI et al. 1990). These species are dominant particularly in the ecosystem named "Restinga" a typical short and sparse vegetation covering a sandy soil habitat. In spite of more than 15 cacti species occur in the study areas only these two were used by $S$. cerei larvae.

Immatures and behaviour. Eggs reddish, $1 \mathrm{~mm}$ lenght, elliptic with one side bigger than the other, shaped like a dew drop. Eggs are laid singly or in small groups of up to seven, mainly on the thorns (1 egg), or on floral buds (two or more). Eggs are parasitized by Trichogramma sp. (Hymenoptera, Trichogrammatidae). Two samples of 10 and 15 eggs showed 60 and $80 \%$ infestation, respectively. 
Larvae. Last instar are gray greenish dorsally and greenish ventrally, without dots except for black ones on prothorax and last segment of abdomen; 3 $\mathrm{cm}$ length (Figs 5-8). Initially the larvae feed on the floral buds, flowers, fruits, or directly on the cladodium. They complete their development in a chamber inside the cladodium, going through six to seven instars lasting 50 days in average $(n=20)$. The larvae build a tough aggregation of feces and bits of the host plant next to the entrance of the chamber. These aggregations are feeding ground for several species of Diptera such as Syrphidae, Lonchaeidae, Stratyomiidae, Drosophilidae, Phoridae and Otitidae, and Coleoptera, such as Nitidulidae, Cryptophagidae, Scarabaeidae, Staphylinidae, and Histeridae. Frequently the chamber entrance is also protected by dried flowers or fruits, attached to the plant by silk. Sigelgaita cerei larvae are almost restricted to Pilosocereus arrabidae but in Parque Nacional da Restinga de Jurubatiba (Macaé, Rio de Janeiro) we observed fruits of Cereus obtusus heavily infested by larvae of this species. Five of ten individual larvae collected in this sample were parasitized by a endoparasitoid and gregarious species of Braconidae.

Pupae (Figs 9-12). Larvae pupate in the sandy ground, a few centimeters below surface, spining a soft cocoon covered with sand, that gives a kind of camouflage to the cocoon. We also observed several reddish air globules probably similar to those found by MANN (1969) in S. transilis. Pupal time is about 18 days $(\mathrm{n}=10)$. Therefore, total larval plus pupal stage lasted 68 days under laboratory conditions $\left(24^{\circ} \mathrm{C} \pm 2\right.$, and $70 \pm 10 \%$, humidity).

Empty chambers built by this species are frequently occupied by spiders, bees and ants, either for sheltering or nesting. Ants, especially Camponotus crassus Mayr 1862, C. cingulatus Mayr 1862 and Solenopsis sp., are the most common guests. C. crassus occurs all year round.

Larvae of S. cerei can be found in different stages throughout the year. Given the abundance of this species throughout the habitat, these chambers might provide important nesting ground to the ant population, as the sandy soil, with many exposed spaces, offers limited nesting sites. Therefore these larval chambers could be important nesting sites either for arboreal ants, or for ground ants such as C. crassus. It is important to notice that this ant species was also recorded as one of the most important dwellers of abandoned galleries made by lepidopterous larvae in the Cerrado (MORAIS \& BENSON 1988). The mechanical damages by the larvae of this species are also considered one of the principal causes of initiation of rotting by several cactophilic species of yeasts. This moth species is part of a diverse insect community associated with Pilosocereus arrabidae interacting mutualisticaly, feeding and dispersing yeasts species among cactus (RoSA et al. 1994).

ACKNOWLEDGEMENTS. We thank P. Ormindo and Rogério Fonseca for their help in drawing and rearing the larvae, respectively and to Moema Becker for correcting the English version. We also thank FAPERJ and CNPq ("Programa de Ecologia de Longa Duração - PELD - e processo 468664/00-9") for the financial support and scholarship and to IBAMA for the license to study in the "Parque Nacional da Restinga de Jurubatiba".

Revta bras. Zool. 19 (Supl. 1): 299 - 304, 2002 


\section{REFERENCES}

Araújo, D.S.D. 1984. Comunidades vegetais, p. 159-226. In: L.D. LaCerda; D.S.D. Araújo; R. CERqueIra \& B. TURCQ (Eds) Restingas: Origem, estrutura e processos. Niterói, EDUFF, 475p. Heinrich, C. 1956. American moths of the subfamily Phycitinae. Bull. U.S. Nat. Mus. 207: 1-581.

ManN, J. 1969. Cactus-feeding insects and mites. Bull. U.S. Nat. Mus. 256: 1-158.

MORAIS, H.C. \& W.W. BENSON. 1988. Recolonização de vegetação de cerrado após queimada, por formigas arborícolas. Rev. Brasil. Biol. 48 (3): 459-466.

Rizzini, C.M.; C. Pereira; E.M.L. OCChioni \& F.W. AgareZ. 1990. Considerações sobre a ocorrência de Cactaceae na APA de Maricá, Rio de Janeiro, Brasil. Acta Bot. Brasilica 4 (2): 171-182.

Rosa, C.A.; P.B. Morais; A.N. Hagler; L.C. MendonçA-Hagler \& R.F. Monteiro. 1994. Yeast communities of the cactus Pilosocereus arrabidae and associated insects in the sandy coastal dune. Antoine Leuwenhoek 65: 55-62.

Received in 11.III.2002; accepted in 03.VII.2002. 